Volume 7, Number 1, 2021

\title{
Adsorption Properties of Combined Vegetable Powders
}

\author{
Zhanna Petrova, Kateryna Samoilenko* \\ Institute of Engineering Thermophysics of NAS of Ukraine, Str. Bulakhovskogo, 2, Kyiv, 03164, Ukraine \\ Received: March 26, 2021. Revised: May 06, 2021. Accepted: May 14, 2021.
}

(c) 2021 The Authors. Published by Lviv Polytechnic National University.

\begin{abstract}
Equilibrium moisture of combined vegetable powders obtained from vegetable raw materials is one of the main technological properties and it is important. Because the final moisture content and energy costs for the dehydration process depend on this indicator. To determine the equilibrium humidity of the samples of combined powders, depending on the relative humidity, the tensometric (static) method of Van Bamelen was used. As a result of researches, kinetic curves of adsorption of water vapor of mono- and combined vegetable powders, which were compared among themselves, were received. Comparison of adsorption isotherms, despite the same nature of these isotherms, show that these materials are capillary-porous colloidal bodies and have the same forms of moisture binding (adsorption, capillary and osmotic) and at the same time differ significantly from each other by equilibrium humidity. When storing composite powders in order to preserve their technological properties, it is recommended to maintain the following conditions in the room: humidity not more than $60 \%$ at the temperature of $20-25{ }^{\circ} \mathrm{C}$ and to pack hermetically.
\end{abstract}

Keywords: food combined powders; adsorption properties; colloidal capillary-porous materials; drying.

\section{Definition of the problem to be solved}

One of the topical issues in the field of nutrition is high quality processing of vegetable raw materials (colloidal capillary-porous materials) and improvement of energy efficiency of drying processes. An important task in the processing of vegetable raw materials by dehydration is to reduce energy consumption for the drying process. Vegetable raw materials need to be dried to equilibrium humidity, because drying to a humidity lower than equilibrium leads to increased energy consumption if we do not get a powdery material [1]-[3].

In this paper, we investigated the sorption of combined plant powders, which belong to 4 groups of functional foods (according to the classification of the main plant functional ingredients, Doctor of Engineering Zh. Petrova) these are antioxidant, phytoestrogenic, folate-containing and prebiotic [4]-[6].

When considering the technological properties of samples of combined powders obtained from vegetables and fruit, the equilibrium humidity is important, which determines not only the conditions of their storage, but also the final moisture content during drying.

The powders have external and internal developed surfaces and therefore actively adsorb water from the surrounding air. Adsorption on the surface of a solid dispersed body occurs spontaneously and continues until the dynamic equilibrium state of this thermodynamic system is established.

Analytical structure of sorption isotherms of dispersed materials is complicated by the variety of forms of moisture bonding with dispersed materials. Most researchers have chosen the empirical way to determine the equilibrium humidity, because the equation of the sorption isotherm is derived analytically, only for Lengmiur's isotherms of capillary-porous bodies.

\footnotetext{
* Corresponding author. Email address: SamoilenkoKM@ nas.gov.ua
}

This paper should be cited as: Zh. Petrova, K. Samoilenko. Adsorption properties of combined vegetable powders. Energy Engineering and Control Systems, 2021, Vol. 7, No. 1, pp. 38 - 47. https://doi.org/10.23939/jeecs2021.01.038 


\section{Analysis of the recent publications and research works on the problem}

According to the literature, this area has a limited amount of information and therefore requires in-depth study and is a relevant area of research. Previously, studies of the adsorption of antioxidant plant powders based on carotenoids. Based on the isotherms of adsorption of antioxidant powders based on carotenoids, it is proved that the lowest equilibrium moisture of the combined powders has oat-carrot, and the highest equilibrium humidity at $\varphi=0.6-0.7$ have monopowders [7]-[8].

\section{Formulation of the goal of the paper}

The shelf life of food, as a rule, is determined based on commercial requirements, taking into account the time required for delivery of this product to the consumer, the temperature in the period from production to sale. A realistic estimate of shelf life can only be obtained from research and compliance with storage requirements. Storage conditions for research should reflect the temperature and humidity conditions, in which these powders will be stored. For Ukraine, the room temperature is $22-25{ }^{\circ} \mathrm{C}$, and the relative humidity for this temperature is $60-70 \%$. Therefore, the adsorption properties of combined plant powders were investigated in order to select the optimal storage conditions.

\section{Presentation and discussion of the research results}

To determine the equilibrium humidity of the samples of combined powders, depending on the relative humidity $\varphi$, the tensometric (static) method of Van Bamelen was used. The essence of the method is that the samples of material with predetermined moisture content are kept in desiccators over aqueous solutions of sulfuric acid. The known concentration of solutions corresponds at a given temperature to a certain partial vapor pressure, namely the appropriate value of the relative pressure $p / p_{s}$.

Table 1. Relative humidity $\varphi$ over solutions $\mathrm{H}_{2} \mathrm{SO}_{4}$ at 760 millimeters of mercury

\begin{tabular}{|c|c|c|c|c|c|c|}
\hline \multirow{2}{*}{\begin{tabular}{c}
\multirow{2}{*}{ weight $\%$} \\
$\mathrm{SO}_{4}$,
\end{tabular}} & \multicolumn{7}{|c|}{$\varphi$} \\
\cline { 2 - 7 } & \multicolumn{7}{|c|}{ Steam temperature, ${ }^{\circ} \mathrm{C}$} \\
\cline { 2 - 7 } & 10 & 15 & 20 & 25 & 30 & 35 \\
\hline 10 & 0.956 & 0.962 & 0.981 & 0.956 & 0.955 & 0.956 \\
\hline 20 & 0.880 & 0.877 & 0.878 & 0.880 & 0.880 & 0.882 \\
\hline 25 & 0.814 & 0.821 & 0.827 & 0.825 & 0.826 & 0.828 \\
\hline 30 & 0.749 & 0.759 & 0.753 & 0.754 & 0.754 & 0.756 \\
\hline 35 & 0.673 & 0.680 & 0.662 & 0.665 & 0.660 & 0.669 \\
\hline 40 & 0.565 & 0.571 & 0.559 & 0.564 & 0.569 & 0.574 \\
\hline 45 & 0.456 & 0.461 & 0.456 & 0.463 & 0.465 & 0.472 \\
\hline 50 & 0.348 & 0.352 & 0.354 & 0.358 & 0.361 & 0.368 \\
\hline 55 & 0.250 & 0.250 & 0.251 & 0.291 & 0.264 & 0.268 \\
\hline 60 & 0.163 & 0.164 & 0.160 & 0.164 & 0.170 & 0.175 \\
\hline 65 & 0.0869 & 0.0938 & 0.0913 & 0.0962 & 0.101 & 0.104 \\
\hline 70 & 0.0326 & 0.0391 & 0.0456 & 0.0379 & 0.0409 & 0.0451 \\
\hline 75 & 0.0109 & 0.0156 & 0.0171 & 0.0168 & 0.0189 & 0.0190 \\
\hline 80 & 0.00434 & 0.00469 & 0.00570 & 0.00421 & 0.00629 & 0.00711 \\
\hline 85 & 0.00109 & 0.00156 & 0.00171 & 0.00168 & 0.00189 & 0.00190 \\
\hline 90 & 0.000217 & 0.000235 & 0.000285 & 0.000337 & 0.000314 & 0.000474 \\
\hline
\end{tabular}

The transfer potential in the adsorption process is the partial vapor pressure. Equilibrium in the system occurs when the partial pressure of air vapor $p_{\text {air vapor }}$ and steam in a thin layer over the material $p_{\text {mat.vapor }}$ are aligned, namely at equality of temperatures of air and material $p_{\text {air vapor }}=p_{\text {mat.vapor }}$. Under these conditions, the material receives a constant humidity $W_{\text {equilib}}$, which is called equilibrium, and the equilibrium in the system is understood only as dynamic. If the material absorbs moisture $p_{\text {air vapor }}>p_{\text {mat.vapor }}$ there is a sorption, if it gives off moisture $p_{\text {air vapor }}>p_{\text {mat.vapor }}$ there is desorption. 
At equilibrium, the humidity of the material $W_{\text {equilib }}$ is the same at any point.

The content of water vapor in the air is determined by the relative humidity $\varphi$, equal to the ratio of the partial pressure of air vapor $p_{\text {air vapor }}$ to saturation pressure $p_{\text {satur }}$ at the same temperature over water.

Since the reference literature shows the dependence of water vapor pressure on sulfuric acid solutions in $\mathrm{mm} \mathrm{Hg}$ on concentration $\mathrm{H}_{2} \mathrm{SO}_{4}$ in weight $\%$, the recalculation of this pressure on relative humidity is carried out according to the following formula:

$$
\varphi=\frac{p}{p_{S}}
$$

where $p$ and $p_{s}$ are partial pressure and water vapor saturation pressure at pressure $760 \mathrm{~mm} \mathrm{Hg}$ and temperatures covering the possible range of their change in the experiment. The results of the recalculation are presented in Table 1.

The reference books in tabular form show the dependence of water vapor pressure over solutions on weight $\%$ of $\mathrm{H}_{2} \mathrm{SO}_{4}$ in solution (on its concentration), and also dependence of $\mathrm{H}_{2} \mathrm{SO}_{4}$ contents in $\mathrm{g}$ in $100 \mathrm{~g}$ solution and in 1 litre solution on the density of the solution in $\mathrm{g} / \mathrm{cm}^{3}$ at $20^{\circ} \mathrm{C}$ for acid with density of 1.8305 (Table 2).

Table 2. Properties of aqueous solutions of sulfuric acid at temperature of $20^{\circ} \mathrm{C}$

\begin{tabular}{|c|c|c|c|c|}
\hline $\mathrm{H}_{2} \mathrm{SO}_{4}$, weight $\%$ & $\begin{array}{l}p, \text { millimeters of } \\
\text { mercury }\end{array}$ & $\varphi$ & $\begin{array}{l}\text { Density of } \mathrm{H}_{2} \mathrm{SO}_{4} \text { solution, } \\
\qquad \mathrm{g} / \mathrm{cm}^{3}\end{array}$ & Concentration of $\mathrm{H}_{2} \mathrm{SO}_{4}$ solution, $\mathrm{g} / \mathrm{l}$ \\
\hline 10 & 17.2 & 0.981 & 1.066 & 106.6 \\
\hline 20 & 15.4 & 0.878 & 1.139 & 227.9 \\
\hline 25 & 14.5 & 0.827 & 1.178 & 294.6 \\
\hline 30 & 13.2 & 0.753 & 1.219 & 365.6 \\
\hline 35 & 11.6 & 0.662 & 1.260 & 441.0 \\
\hline 40 & 9.8 & 0.559 & 1.303 & 521.1 \\
\hline 45 & 8.0 & 0.456 & 1.348 & 606.4 \\
\hline 50 & 6.2 & 0.354 & 1.395 & 697.5 \\
\hline 55 & 4.4 & 0.251 & 1.445 & 794.8 \\
\hline 60 & 2.8 & 0.160 & 1.498 & 898.8 \\
\hline 65 & 1.6 & 0.0913 & 1.553 & 1010 \\
\hline 70 & 0.8 & 0.0456 & 1.611 & 1127 \\
\hline 75 & 0.3 & 0.0171 & 1.669 & 1252 \\
\hline 80 & 0.1 & 0.00570 & 1.727 & 1382 \\
\hline 85 & 0.003 & 0.00171 & 1.779 & 1512 \\
\hline 90 & 0.05 & 0.000285 & 1.814 & 1633 \\
\hline
\end{tabular}

Since the determination of the equilibrium humidity of the combined powders had to be carried out in the range of relative humidity $\varphi$ from 0.4 to 0.9 , which is typical for production conditions, the required characteristics of sulfuric acid were determined from the conversion Table 1 and reference data. According to the technique of preparation of solutions, as a result of interpolation of the data of table 2, 6 solutions were prepared for 6 different $\varphi$ in the range from 0.4 to 0.9 . The experiments were performed at ambient temperature $20{ }^{\circ} \mathrm{C}$.

Since the equilibrium humidity should be calculated in relation to the absolutely dry mass of the material, because this value, in the processes of sorption-desorption and drying-wetting, remains unchanged, when processing all experimental data, the moisture absorbed by the material was attributed to the mass of absolutely dry material.

Thus, sorption isotherms were obtained $W_{e}^{s}=f(\varphi)$ in the studied interval of relative humidity and sorption kinetics curves $W^{s}=f(\tau)$, since in experiment scheme also provides the ability to record changes in the humidity of the samples in time. The kinetic curves of water vapor adsorption, obtained by the experiments with samples of combined powders whose dispersion is $d<0.5 \mathrm{~mm}$ at the ratio of the components specified for each powder, are shown in Fig. 1 - 7.

Analysis of experimental data shows that all curves are the same character. Within the investigated humidity, they are returned to convexity. 


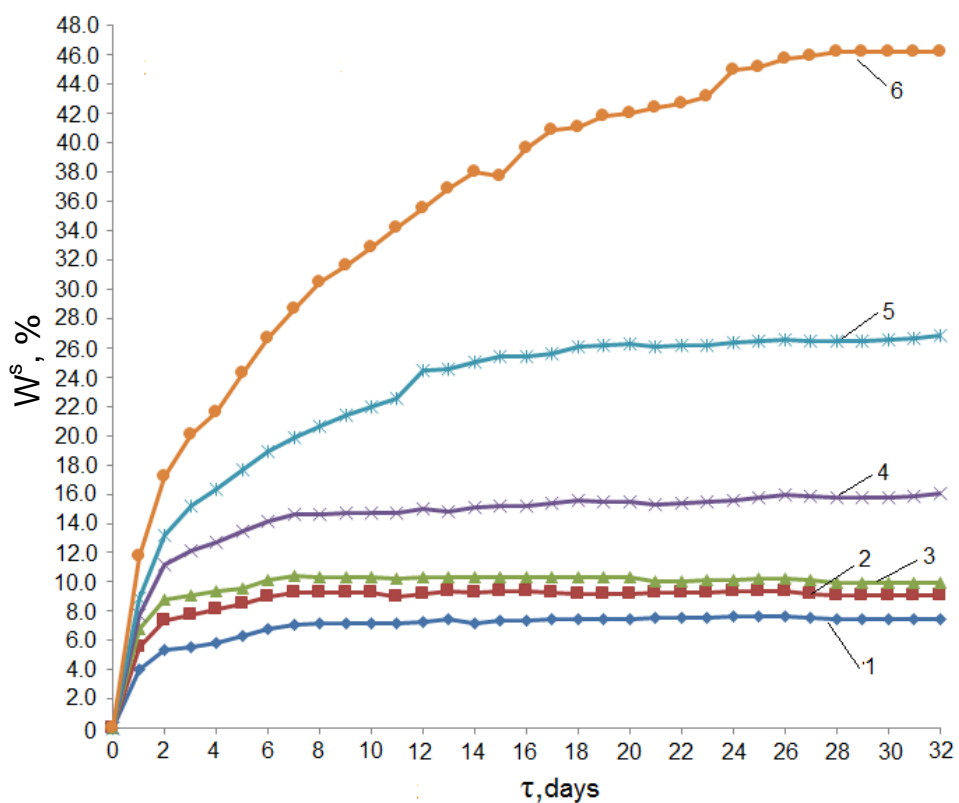

Fig. 1. Kinetic curves of water vapor adsorption of antioxidant powder red beetroot - rhubarb:

$$
\begin{gathered}
1-\varphi=0.4, \rho=1.37 ; 2-\varphi=0.5, \rho=1.33 ; 3-\varphi=0.6, \rho=1.29 ; 4-\varphi=0.7, \rho=1.24 ; \\
5-\varphi=0.8, \rho=1.2 ; 6-\varphi=0.9, \rho=1.13
\end{gathered}
$$

For red beetroot - rhubarb powder at $\varphi=0.4-0.6$ equilibrium is set on days $10-14$, at $\varphi=0.7-0.8$ on days 16 - 19 (Fig. 1). For red beetroot - lemon powder at $\varphi=0.4-0.6$ equilibrium is set on days $8-10$, at $\varphi=0.7-0.8$ on days 18 - 19 (Fig. 2).

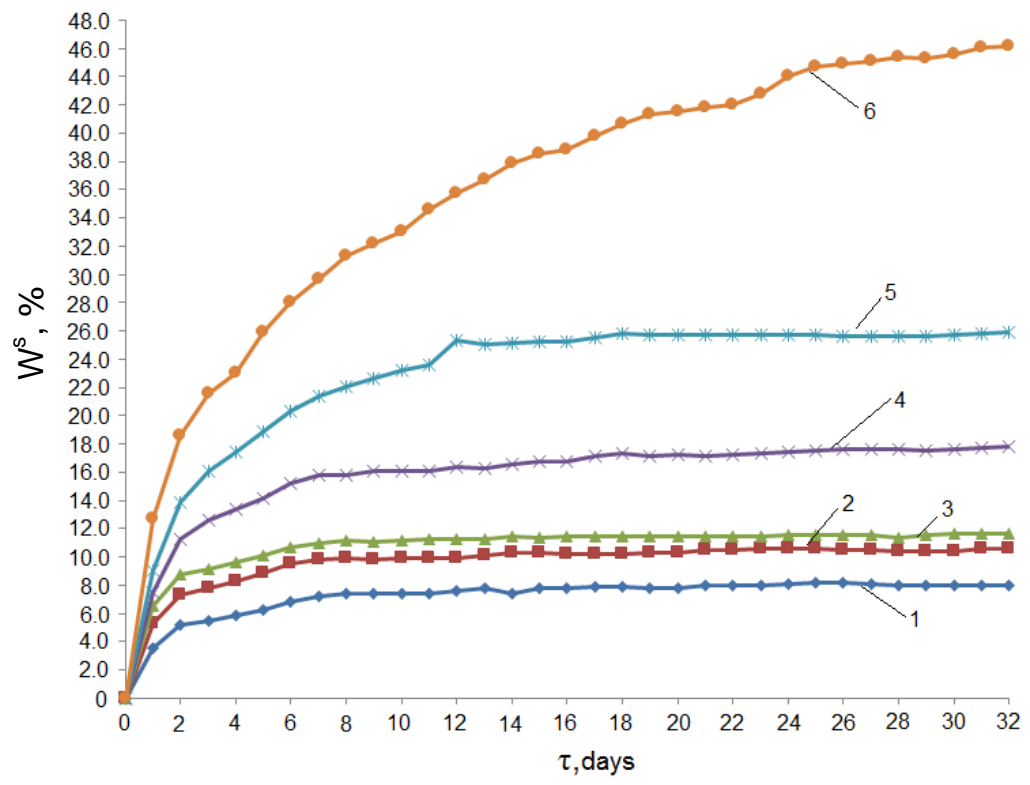

Fig. 2. Kinetic curves of water vapor adsorption of antioxidant powder red beetroot - lemon:

$$
\begin{gathered}
1-\varphi=0.4, \rho=1.37 ; 2-\varphi=0.5, \rho=1.33 ; 3-\varphi=0.6, \rho=1.29 ; 4-\varphi=0.7, \rho=1.24 ; \\
5-\varphi=0.8, \rho=1.2 ; 6-\varphi=0.9, \rho=1.13
\end{gathered}
$$




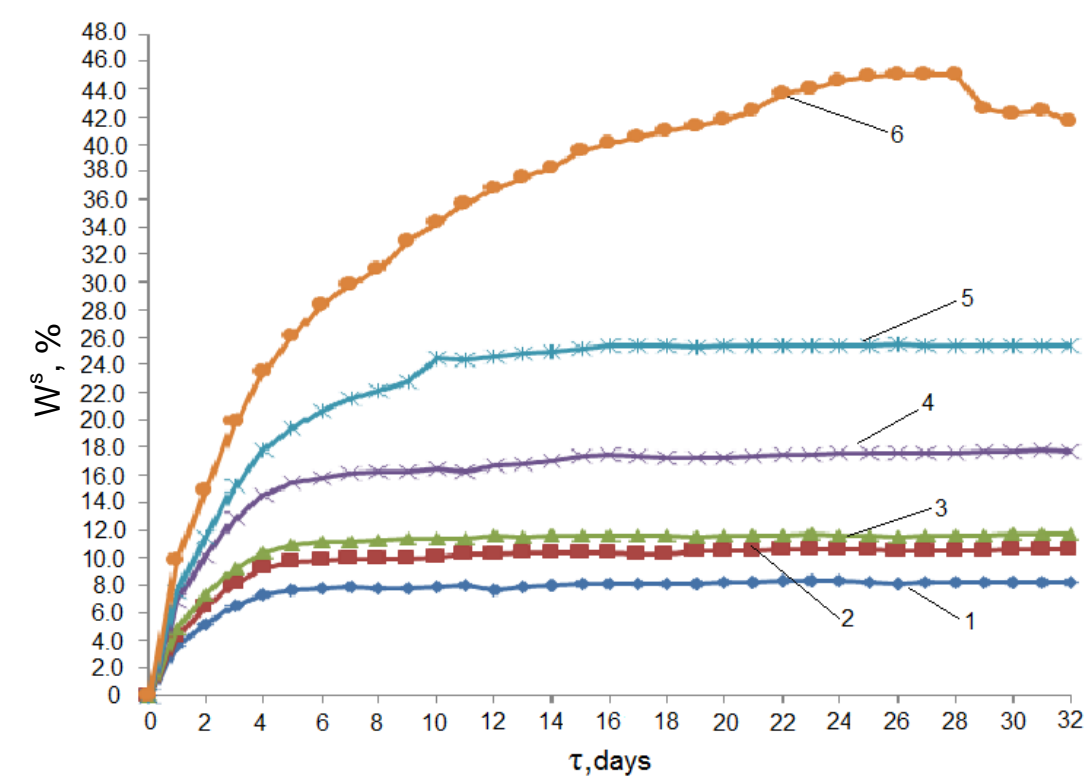

Fig. 3. Kinetic curves of water vapor adsorption of phytoestrogenic powder (pear-zucchini):

$$
\begin{gathered}
1-\varphi=0.4, \rho=1.37 ; 2-\varphi=0.5, \rho=1.33 ; 3-\varphi=0.6, \rho=1.29 ; 4-\varphi=0.7, \rho=1.24 ; \\
5-\varphi=0.8, \rho=1.2 ; 6-\varphi=0.9, \rho=1.13
\end{gathered}
$$

For pear-zucchini powder at $\varphi=0.4-0.6$ equilibrium is set on days $5-6$, at $\varphi=0.7-0.8$ on days $10-12$ (Fig. 3). For apple-spinach powder at $\varphi=0.4-0.6$ equilibrium is set on days $12-13$, at $\varphi=0.7-0.8$ on days $18-23$ (Fig. 4). For apple-banana powder at $\varphi=0.4-0.6$ equilibrium is set on days $4-6$, at $\varphi=0.7-0.8$ on days $11-12$ (Fig. 5).

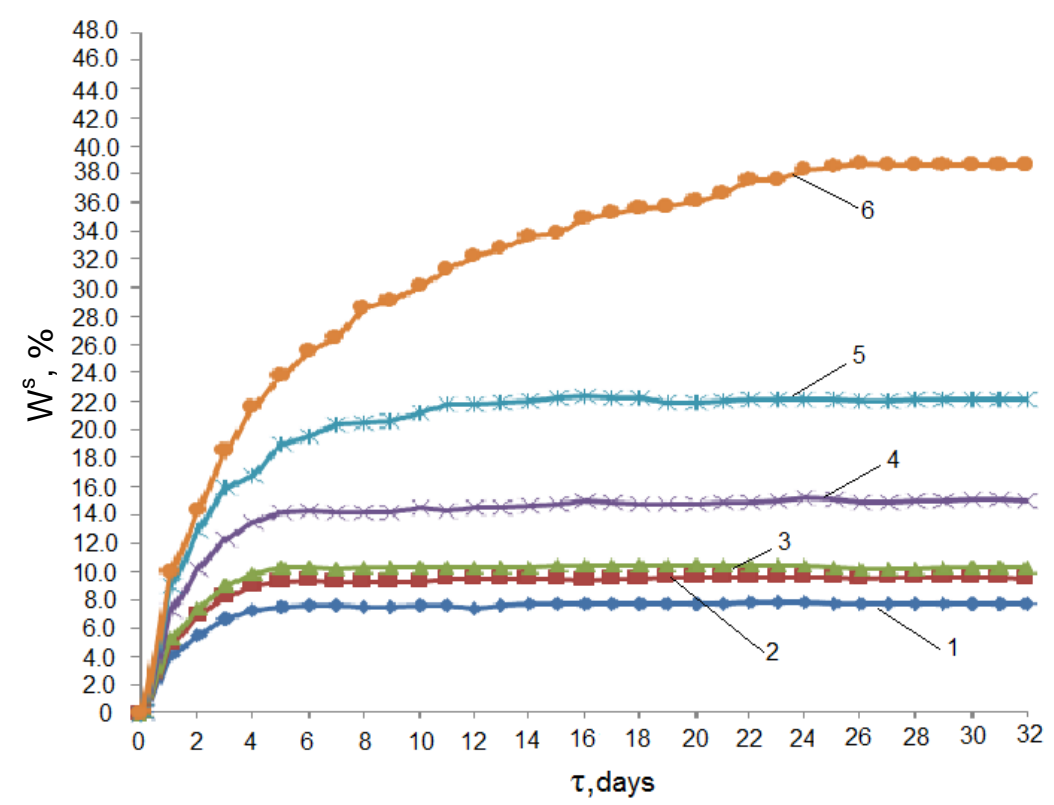

Fig. 4. Kinetic curves of water vapor adsorption of folate-containing and prebiotic powders apple - spinach:

$$
\begin{gathered}
1-\varphi=0.4, \rho=1.37 ; 2-\varphi=0.5, \rho=1.33 ; 3-\varphi=0.6, \rho=1.29 ; 4-\varphi=0.7, \rho=1.24 ; \\
5-\varphi=0.8, \rho=1.2 ; 6-\varphi=0.9, \rho=1.13
\end{gathered}
$$




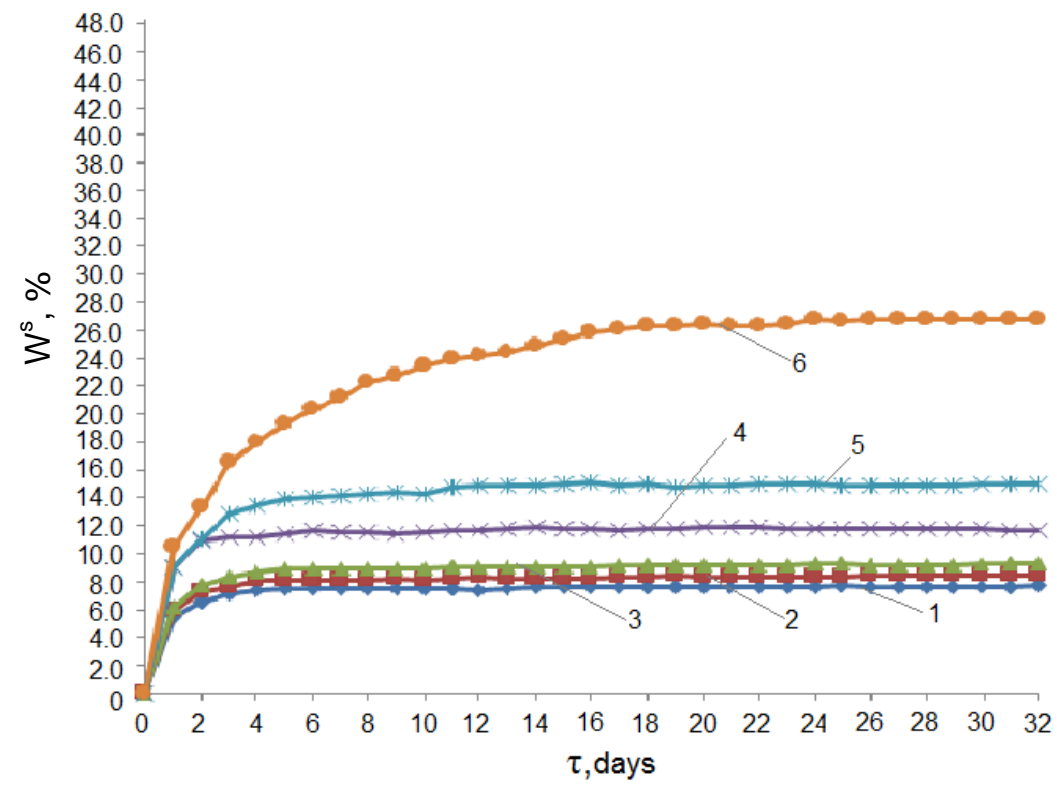

Fig. 5. Kinetic curves of water vapor adsorption of folate-containing and prebiotic powders apple-banana:

$$
\begin{gathered}
1-\varphi=0.4, \rho=1.37 ; 2-\varphi=0.5, \rho=1.33 ; 3-\varphi=0.6, \rho=1.29 ; 4-\varphi=0.7, \rho=1.24 ; \\
5-\varphi=0.8, \rho=1.2 ; 6-\varphi=0.9, \rho=1.13
\end{gathered}
$$

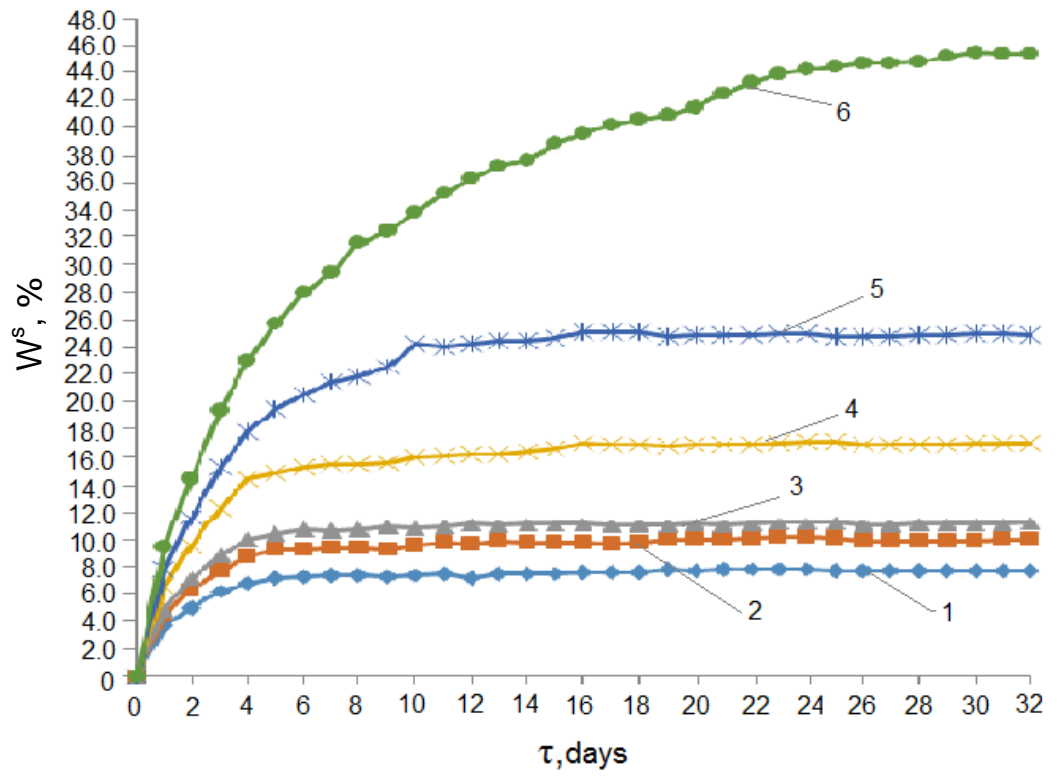

Fig. 6. Kinetic curves of water vapor adsorption of folate-containing and prebiotic powders apple-zucchini:

$$
\begin{gathered}
1-\varphi=0.4, \rho=1.37 ; 2-\varphi=0.5, \rho=1.33 ; 3-\varphi=0.6, \rho=1.29 ; 4-\varphi=0.7, \rho=1.24 ; \\
5-\varphi=0.8, \rho=1.2 ; 6-\varphi=0.9, \rho=1.13
\end{gathered}
$$




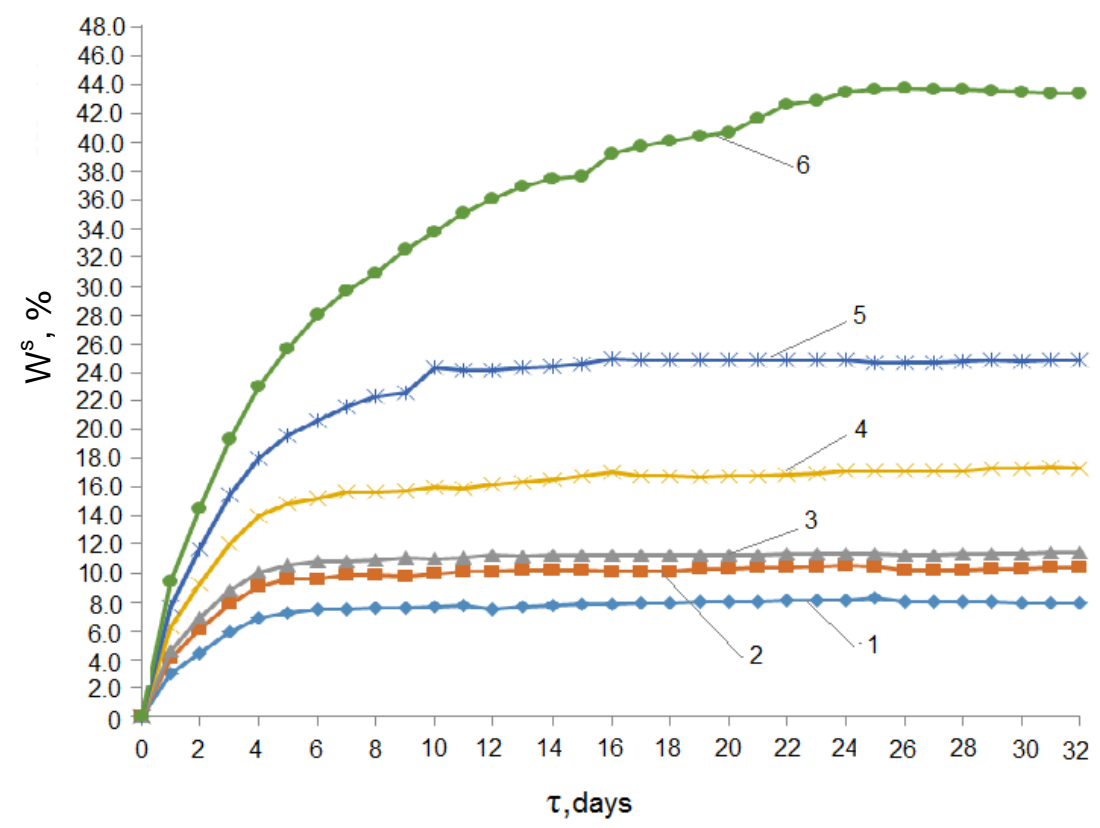

Fig. 7. Kinetic curves of water vapor adsorption of folate-containing and prebiotic powders apple pomace - zucchini:

$$
\begin{gathered}
1-\varphi=0.4, \rho=1.37 ; 2-\varphi=0.5, \rho=1.33 ; 3-\varphi=0.6, \rho=1.29 ; 4-\varphi=0.7, \rho=1.24 ; \\
5-\varphi=0.8, \rho=1.2 ; 6-\varphi=0.9, \rho=1.13
\end{gathered}
$$
(Fig. 6).

For apple-zucchini powder at $\varphi=0.4-0.6$ equilibrium is set on days $12-13$, at $\varphi=0.7-0.8$ on days $15-16$

For apple pomace - zucchini at $\varphi=0.4-0.6$ equilibrium is set on days $10-12$, at $\varphi=0.7-0.8$ on days $16-17$ (Fig. 7).

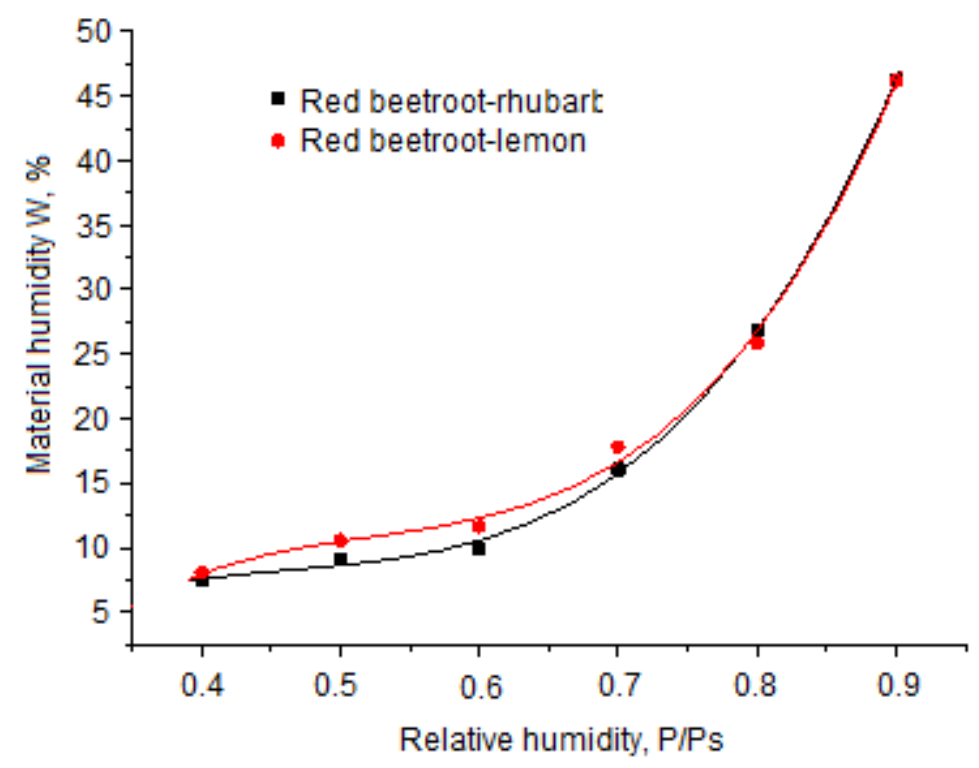

Fig. 8. Isotherms of water vapor adsorption of beet-containing powders 
On the basis of experimental data on the equilibrium moisture content, water vapor adsorption isotherms of functional powders were constructed (Fig. 8-11). Equilibrium humidity of beet-containing powders is approximately the same when $\varphi=0.6-10 W_{e}^{s}=12 \%$ (Fig. 8).

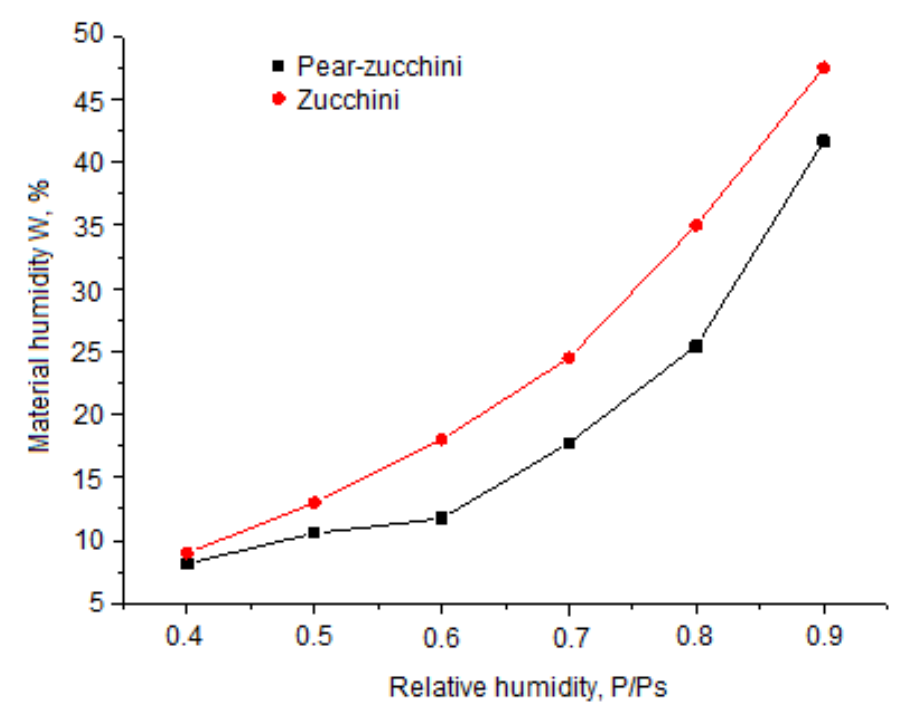

Fig. 9. Comparison adsorption isotherms of phytoestrogenic raw materials with mono powders (pear-zucchini and zucchini)

In phytoestrogens (Fig. 9) there is the same trend in equilibrium humidity as in antioxidants. Equilibrium humidity of zucchini monopowder at $\varphi=0.6$ is $W_{e}^{s}=17.5 \%$, and composite pear-zucchini powder with the same $\varphi$ total $W_{e}^{s}=11 \%$.

In folate-containing powders (Fig. 10) the equilibrium moisture of spinach monopowder at $\varphi=0.6$ is $W_{e}^{s}=12 \%$, while the composition of spinach-apple $W_{e}^{s}=10 \%$.

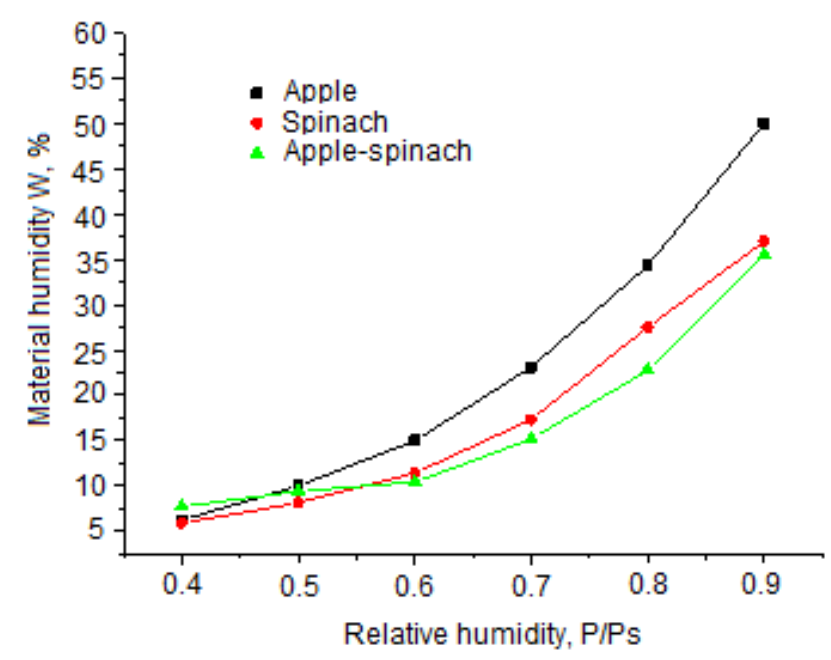

Fig. 10. Comparison of adsorption isotherms of folate-containing powders in comparison with mono powders (apple, spinach, apple-spinach)

In prebiotic powders (Fig. 11) equilibrium humidity of mono powder from apples at $\varphi=0.6$ is $W_{e}^{s}=14 \%$, while the composition of apple-zucchini and apple zucchini pomace equilibrium humidity is the same and is $W_{e}^{s}=10 \%$. 


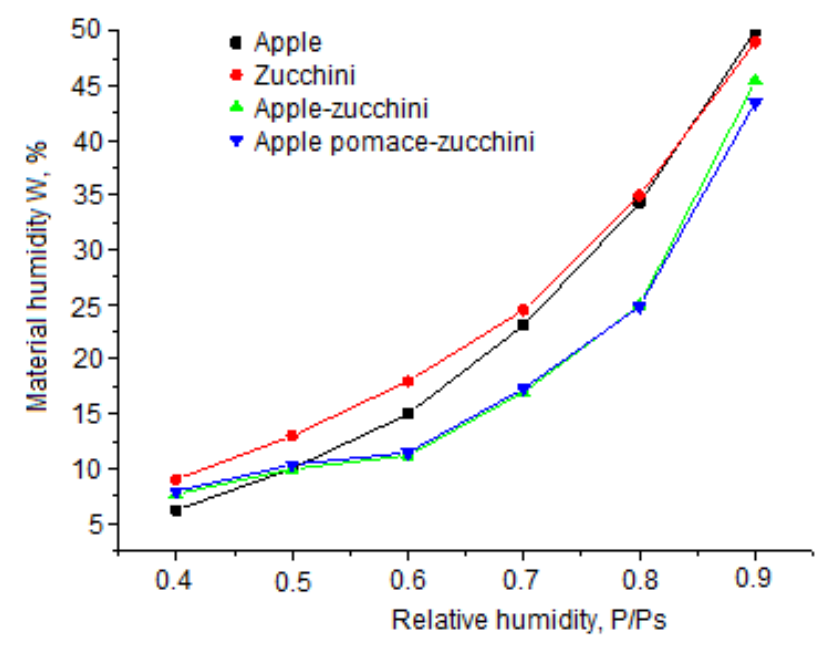

Fig. 11. Isotherms of water vapor adsorption of prebiotic powders

Comparisons of adsorption isotherms of monopowders and combined functional powders (Fig. 8 - 11), despite the same nature of these isotherms, show that these materials are capillary-porous colloidal bodies and have the same forms of moisture binding (adsorption, capillary and osmotic) at the same time differ significantly from each other in equilibrium humidity. This can be explained by their different chemical composition.

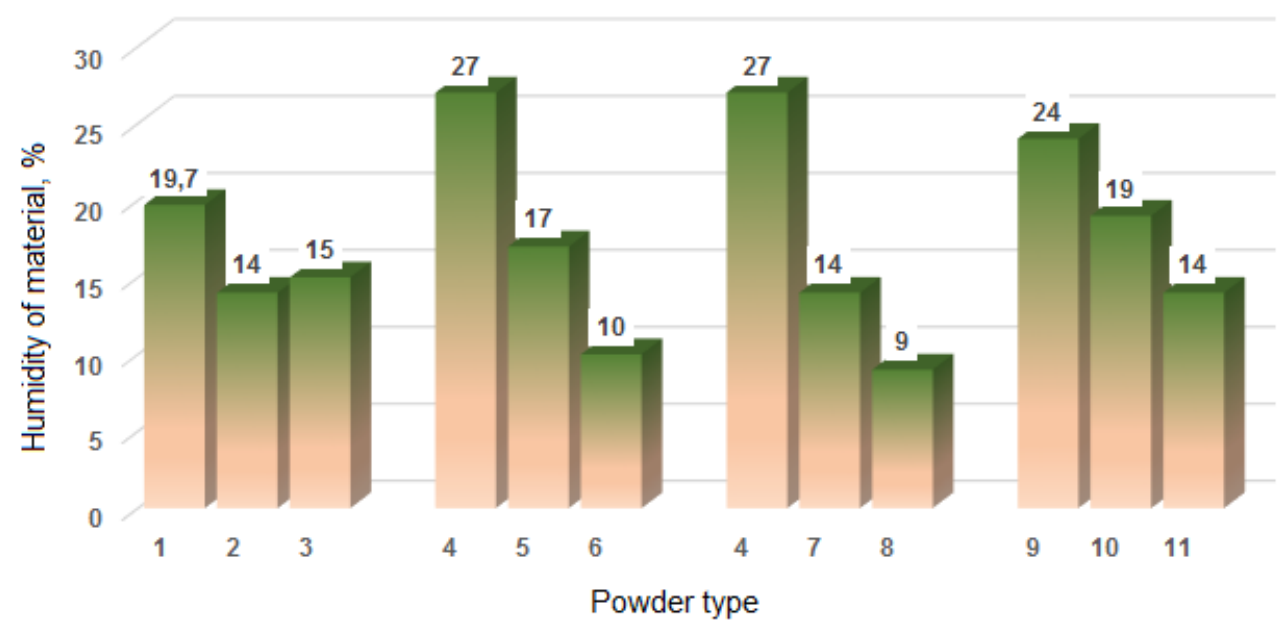

Fig. 12. Comparison of adsorption isotherms of food mono- and combined powders

$$
\varphi=0.7 \%, t=20^{\circ} \mathrm{C}, d<0.5 \mathrm{~mm}:
$$

1 - red beetroot; 2 - red beetroot-rhubarb; 3 - red beetroot-lemon; 4 - apple; 5 - spinach; 6 - spinach-apple; 7 - banana; 8 - banana-apple; 9 - zucchini; 10 - apple pomace; 11 - apple pomace-zucchini.

Fig. 12 shows the equilibrium humidity of mono and combined powders at relative humidity $\varphi=0.7 \%$. The tendency to decrease the equilibrium humidity is observed in all antioxidant powders.

Comparison of sorption of folate-containing powders with monopowders has a similar nature. Apple and spinach powders have an equilibrium humidity of $27 \%$ and $17 \%$ respectively. And for spinach-apple it is only $12 \%$.

Prebiotic powder (i.e. apple pomace-zucchini) has an equilibrium humidity of $14.4 \%$, which is much lower than that for the powder from apple pomace (19\%) and zucchini (24\%).

Based on the adsorption isotherms (Fig. 12), the lowest equilibrium moisture $W_{e}^{s}=8 \%$ of the combined powders is observed for banana-apple, and the highest for red beetroot-lemon $W_{e}^{s}=15 \%$. 


\title{
5. Conclusion
}

Monopowders at $\varphi=0.4-0.7$ have the highest equilibrium humidity. In composite powders, this ability decreases, which leads to improved storage conditions of these powders. For example, the equilibrium humidity of red beetroot-rhubarb and red beetroot-lemon powders is $14 \%$ and $15 \%$ respectively. And for red beetroot it is $19.7 \%$. Equilibrium humidity of apple powder is $27 \%$. For spinach powder it is $17 \%$, and for spinach-apple composition it is only $12 \%$. The tendency to decrease in the equilibrium humidity of combined powders is observed in all groups of vegetable powders. It is obvious that during the processing of the developed plant compositions at the nano level there is an interaction of chemical components of raw materials. This leads to the formation of compositions with new properties that have better characteristics than the mono-raw materials from which they are formed. When storing composite powders in order to preserve their technological properties, it is recommended to maintain the following conditions in the room: humidity not more than $60 \%$ at the temperature of $20-25{ }^{\circ} \mathrm{C}$ and to use hermetic packaging.

\section{References}

[1] Zh.O. Petrova, Yu.F Sniezhkin, V.M. Paziuk, K.M. Samoilenko Drying of antioxidant composite materials based on table beet. Energy engineering and control systems. Vol. 1, No. 1, 2015, pp. 25-28.

[2] Yu. F. Sniezhkin, Zh. O. Petrova, V. M. Paziuk Energy efficient heat technologies for the production of functional food powders. Monograph. Vinnytsia (VNAU), 2016, 456. (in Ukrainian)

[3] Yu.F. Sniezhkin, L.A. Boriak, A.A. Khavyn Energy-saving heat technologies for the production of powders from secondary raw materials. Scientific thought, 2004, 228. (in Russian)

[4] Zh.O. Petrova, Yu.F. Sniezhkin. Energy efficient heat technologies for processing functional raw materials. Scientific thought, 2018, 187. (in Ukrainian)

[5] Yu.F. Sniezhkin, Zh.O. Petrova Food powders from vegetable raw materials. Classification, production methods, market analysis. Biotechnology, Issue 3 (5), 2010, pp. 43-49. (in Ukrainian)

[6] Yu.F. Sniezhkin, Zh.O. Petrova, O.P. Samoilenko, K.M. Hetmaniuk Some technological characteristics of functional powders. Scientific works of the Odessa National Academy of Food Technologies. Issue 38, Vol. 2, 2010, pp. 152-156. (in Ukrainian)

[7] Zh.O. Petrova, Yu.F. Sniezhkin, K.M. Hetmaniuk Investigation of adsorption processes of antioxidant plant powders. Scientific works of the Odessa National Academy of Food Technologies. Issue 45 Vol. 2, 2014, pp. 21- 25. (in Ukrainian)

[8] B.L. Flaumenbaum, A.T. Bezusov, V.M. Storozhuk, H.P. Khomych. Physico-chemical and biological bases of canning production. Odessa, Druk, 2006, 400. (in Ukrainian)

\section{Адсорбційні властивості комбінованих рослинних порошків}

\author{
Жанна Петрова, Катерина Самойленко \\ Інститут технічної теплофізики НАН Украӥни, вул. Булаховського, 2, м. Київ, 03164, Украӥна
}

\section{Анотація}

Однією із основних технологічних властивостей комбінованих рослинних порошків, одержаних 3 рослинної сировини, важливе значення має рівноважна вологість. Оскільки від цього показника залежить кінцевий вологовміст та енергетичні затрати на процес зневоднення. Для визначення рівноважної вологості зразків комбінованих порошків залежно від відносної вологості повітря застосовувався тензометричний (статичний) метод Ван Бамелена. В результаті досліджень отримано кінетичні криві адсорбції водяної пари моно- та комбінованих рослинних порошків, які порівнювались між собою. Порівняння ізотерм адсорбції, що не дивлячись на однаковий характер цих ізотерм, які показують, що ці матеріали представляють собою капілярно-пористі колоїдні тіла і маючи однакові форми зв’язування вологи (адсорбційну, капілярну та осмотичну) в той же час суттєво відрізняються один від одного рівноважною вологістю. При зберіганні композиційних порошків 3 метою збереження їхніх технологічних властивостей рекомендується підтримувати в приміщенні наступні умови: вологість повітря 60 - 70 \% при температурі 20 - $25^{\circ} \mathrm{C}$ та герметично їх запаковувати.

Ключові слова: харчові комбіновані порошки; адсорбційні властивості; колоїдні капілярно-пористі матеріали; сушіння. 